\title{
The Law Applicable to Petrolume Contract
}

\author{
Maria Joao Mimoso* \\ Portucalense Institute for Legal Research (IJP), Research Nucleus Polytechnic Institute of Maia (N2i), Colombia
}

Received: 19/06/2020

Accepted: 02/08/2020

Published: 20/09/2020

\begin{abstract}
As the oil industry is the largest industry in the world, and with the oil contract as the object of these activities, it is imperative to discern some of the issues surrounding it. Producing countries intend to maximize profits from the exploitation of their natural wealth, while consuming countries want to guarantee supply at the lowest possible price. It is important to understand the focus of conflicts in this sector. These are linked, on the one hand, to the need for oil, the decrease in new reserves and the increase in its exploitation. On the other hand, we have the political instability of the producing countries, the disrespect for the environment and social rights of the population on the producing States. This contract has the State and the investor as protagonists. They are often concluded under the aegis of bilateral or multilateral investment agreements between the producer country and the investor's country of origin. Since they are strategic natural resources, the producing State seeks to safeguard the interests of its population. Thus, it is common to include special clauses, maxime stabilization clauses and arbitration clauses. In its regulation, whether in the negotiation or conclusion stages of the contract or even in the dispute resolution phase, an appeal to International Commercial Law is required, covering both UNIDROIT principles and Lex mercatoria, configured here in Lex Petrolia.
\end{abstract}

Keywords: Agreement, Clauses, Conflicts, Lex Petrolia, Regulation

\section{Introduction}

With the development of the world economy, new and complex commercial relations have emerged, giving rise to new contractual models. Consequently, international trade has not only contributed to the creation of new instruments, but also to the improvement of some of the existing ones. One of the most striking sectors of international trade is, without a doubt, the oil industry, which, due to the high costs it presupposes, is able to attract investors from different states. It will be difficult to even imagine a transaction in the scope of oil that does not involve elements of extraneity. The existence of connections between two or more legal systems, either by the nationality or domicile of the contractors, or by the place of performance of the contract or even through the choice of law by the parties, is a factor that does not detract from the determination of the legal regime of this contract. In order to understand the problem of the applicable law, we must bear in mind the complexity of this contract.[1] The oil industry integrates several activities along what we might call the production chain. We refer to upstream oil exploration, development and production activities; refinement, distribution and marketing activities, downstream; and transportation activities (transportation of oil from production fields to refineries and refined products to final points of sale), midstream. [2,3] The complexity of this contract will inevitably have repercussions on your discipline. After World War I, new players started to intervene in international commercial relations. We are talking about the States, which were compelled to enter transnational trade, thus causing changes in the paradigm of international contracts, including triggering liability limitation clauses and incentive measures for foreign investors, mitigating risks for both parties.

*Corresponding author: Maria Joao Mimoso, Portucalense Institute for Legal Research (IJP), Research Nucleus Polytechnic Institute of Maia (N2i), Colombia. E-mail: mjmarbitragem@gmail.com

\section{The international petroleum contract}

The Petroleum Contract's object is the activities that make up the oil industry, both for producing countries and for consuming countries. The former, maximizing the gains resulting from the exploitation of its natural resources, the latter, ensuring the supply in the greatest possible quantity and at the lowest price. The execution of an oil project covers a variety of contractual instruments, all of which will be integrated into the oil contract, in a broad sense, seeking to regiment the entire production process. Therefore, it becomes necessary to articulate all contractual elements, exhaustively disciplining all behaviors / activities, in order to guarantee all rights and the protagonists involved. Oil, being a nonrenewable and non-eternal resource, conditions its own negotiation. [4,5] Most oil projects are structured according to the life of the project. Therefore, they should cover all stages, from exploration, through development, production, culminating in abandonment. Briefly, we will say that the exploration phase is based on the demand for commercially viable oil for extraction. This phase, with technological modernization, has been carried out through seismic studies and data collection, implementing greater assertiveness in drilling, since it is an extremely costly phase. Having achieved promising results, sampling is made immediately after. Then, an assessment will be made to determine the commercial viability of the discovery. This depends on the business conditions of the company and the legal and financial requirements of the country that holds the oil resources.

After this, development follows, where the necessary infrastructure will be created for an efficient and profitable extraction. Here, the following aspects will be taken into account: geological, location, legal, obtaining hydrocarbons and placing them on the market, number of wells to be drilled and the type of platform to be built. This phase normally lasts for several years and it's the one that requires the most investment. As for production, this usually happens after a decade has elapsed since the beginning of exploration and 
when oil finally flows in increasing quantities. The last stage of the project regards the abandonment. As small areas are concerned, this occurs after a period of seven years of production; if we are dealing with large areas, this will happen after fifty or more years of production. It is in the abandonment phase that the infrastructure is collected and an attempt is made to restore the environment to its original satus quo. Abandonment can occur for several reasons, e.g. problems arising from the financial system of the receiving country (where production is based), as this is not economically advantageous or no longer technologically profitable. It may happen that the company in question, which was in charge of the production process, returns the exploration area to the host State. Thus, it will impose on the latter the continuation of operations and abandon in a timely manner. In this regard, it is referred the dismantling. There are also other factors that can lead to the cessation or suspension of operations, namely, events of force majeure (which suspend obligations until they can be resumed), issues of security, social unrest and political instability in the receiving State. In these cases, there will be no obligation to dismantle.

\section{Protagonists and the Type of Contract}

The contract's parties are the entities that enter into it and, therefore, are bound by its terms and conditions. We refer to governments; national oil companies (NOC, National Oil Companies owned by the State); major international operators (IOC, International Oil Companies); banks; engineering, inspection and drilling companies; transport companies; dispatchers; refineries and trade; advisory services and consultancies. [1,6] However, it is important to underline that the main protagonists are NOCs and IOCs, with the remaining entities being characterized as subsidiaries or ancillaries. NOC's represent States and, as a rule, are the holders of reserves of natural oil resources. They do not give up the right of access to reserves and, therefore, they hire IOCs as service providers. Often, NOC's create branches for them to directly represent them in certain project operations. It was found, from the middle of the 20th century, that many countries nationalized their oil reserves. They wanted the national oil companies to have a monopoly on exploration. It was in this context that the concession contracts between NOC's and IOCs emerged. However, the evolution of the times has demonstrated the need to abandon this contractual regime. Currently, the standard form is based on the shared production contract. [7] The appearance of this new contractual form is mainly due to the result that the concession contracts led to, namely an unequivocal division of profits and the lack of control by the State of the activities carried out by the companies. These did not grant ownership of the technological means used and did not promote the professional training of local agents. This contractual paradigm shift occurred in the 1950s, more specifically after World War II. Host countries (recipients) seek to regain their national pride through oil. [8]

IOCs are, almost always, transnational private companies, which operate in the areas of exploration, refinement and commercialization of oil. They have financial and technological capacity, designated by majors and independents. They explore and develop oil reserves. Often, they participate in the oil contract through a subsidiary. This is due to the concern with the optimization of taxes, the financing of the project, the foreign investment protection regime and legal requirements of the receiving State. The subsidiaries are incorporated within the legal system of the latter, i.e., inserted in a different jurisdiction than the parent company. These companies, due to the magnitude of these contracts, especially in the financial and technological plan, operate through consortia, also seeking, this way, to minimize the liability of the assumed obligations.

\section{The Types of the Contract}

Within the exploiting countries, we find three contractual models: concession contracts, production sharing and service provision contracts. In the concession model, the State, responsible for the oil deposits, gives the right to explore and produce in the deposits to a foreign or national company, the latter assuming the risks and costs of the operation. The hydrocarbons are, therefore, in the possession of the concessionaire, which assumes its control. As compensation for the use of the deposits, the company pays the State royalties and fees, providing compensation for the negative effects caused by the exploration and production of hydrocarbons. Concession contracts are usually related to two phases of the process: exploration and development and production. The production sharing contract is usually concluded between a state-owned company, which represents government interests, and an oil company, or a consortium of companies (contracted), for oil exploration and production, by compensating the parties through of sharing the production of an oil field. The payment due to the contracted company, in product or in kind, is intended for the reimbursement of costs (cost oil) and for its participation in the result of the undertaking (profit oil), with the respective share percentages being defined in the contract. In the service provision contract, the company is hired to carry out the exploration activity, and is compensated for that. This modality can be presented as pure, in which the company would receive a given amount regardless of success, or as a risky contract. In this, the company invests in the exploratory phase, being only reimbursed when the oil is found and produced. It can receive cash or oil, according to the contract.

\section{Lex mercatoria versus lex petrolea?}

International trade and the negotiation of goods, services or values, carried out at global level by economic agents, governed by international commercial practices developed over time, culminated in the consolidation of a set of international commercial rules, known as Lex Mercatoria. [9,10] There have been several contributions to the existence and validity of Lex Mercatoria. Originating in the Middle Ages, it was essentially in the 1960s that it took a new break in the discipline of international commercial relations. It is important to bear in mind that not all authors have the same understanding of what should be understood by this normative source. Despite the differences, there is currently an unquestionable understanding: Lex Mercatoria includes a set of spontaneous customary rules and general principles. [11] This understanding has enabled an extension of Lex Mercatoria's sources, covering not only spontaneous law, the General Principles of Law, the arbitration jurisprudence itself, but also rules emerging from international organizations. [12] We are talking about the UNIDROIT Institute, which has contributed a lot to the discipline of international commercial contracts and the Chamber of International Commerce of Paris (CCI). [10] Differently, but equally controversial, is the characterization of its legal nature as an autonomous legal order. Due to the specificity of the topic we are dealing with, this is not the time to approach it. However, we cannot forget the fact that international trade is a heterogeneous segment, claiming very specific sector specificities. It appears that spontaneous rules have always emerged from certain sectors of international trade. In this sense, and with regard to the oil industry, specific rules have emerged to regulate the contracts that are celebrated in this area. It is urgent to highlight the fact that oil is a sui generis sector, causing heavy investments, where, above all, one can 
find a high spirit of solidarity and cohesion among competitors. This homogeneity, associated with the activity developed by sectorial organizations responsible for compiling uses and drawing up model contracts, led to the emergence of Lex Petrolea. Although it was, for a long time, considered the younger sister of Lex Mercatoria, it has a different position, benefiting from some peculiarities. At least, it has achieved worldwide recognition for the formation of the expected Societas Petroleatorum. Due to its transnational character, without being bound by any national legal order and based on internationally adopted practices, its general acceptance, both by the States that own the resources and by the transnational companies operating in the oil sector, has been recurrent. Lex Petrolea is considered a legal order, created spontaneously, supportive by the players of the transnational oil industry, aimed at protecting the interests at stake - viability and profitability -, presenting itself as a set of autonomous, selfsufficient, valid and effective rules, to discipline the relations in question and at the service of the entire transnational oil community.

The recognition of Lex Mercatoria and Lex Petrolea as autonomous, adequate and special "legal systems", in permanent progress, aiming to meet the interests, needs and problems, with ample room for maneuver due to the parties' private autonomy, manage to discipline international trade agreements' relations, while contributing to their development, allowing the arbitral coutrs to be their guardians, as promoters of their creation, interpretation and application. [13] However, the evolution of Lex Mercatoria is not considered complete, and there is still one way to go. There are those who understand that "international trade operations cannot be completely removed from the competence of state rights", since that normative body is not exclusive, systematic and constant. We understand, however, that, at present, a more evolutionary character must be assigned to it. We cannot forget that the phenomenon of globalization has had repercussions in the legal world, causing a loss of the legifying monopoly by the States, or even of supra-state organizations, such as the European Union. In certain sectors and as a result of the international trade operators dynamics, an expansion and creation of certain instruments / discipline was provided. States continue to have their legitimating power, the power to create instruments to discipline certain conduct / activities. However, at the same time, other forms of standardization appear. The principle of autonomy of will under private international law allows the parties to elect the law which governs their contract. The domestic rights of States, at least the majority, provide for the principle of contractual freedom. We can, then, say that these legitimizing principles have potentiated and potentiate other modes of standardization. [14] The particularities of international trade, from an early age, demanded different protection from the domestic trade operated in each State. The contract as a mandatory bond that it is, generates for the parties the first source of discipline in their relations. And it was from this important topic, not neglecting the principle of the autonomy of the parties that gives it shelter, that certain institutes developed in the context of international commercial relations and disciplines were sedimented. After all, the "gentlemen's agreement" is to be carried out under the terms established between the parties (pacta sunt servanda). We cannot say that the so-called autonomous systems stand out for the inconsistency of control and the absence of sanctioning power. Control is exercised in another way, especially by actors in international trade and by corporate entities in certain sectors, which will also implement other types of sanctions. Namely the exclusion by players in the same market sector. We cannot fail to see that the whole problem that characterizes these autonomous rights in international trade is rooted in the understanding that its defenders or contestants had of a legal order. [15] Some will understand that this will only exist if it is emanated from an authority capable of imposing its rules, others will base this phenomenon beyond the dialectical discourse between sovereign power and spontaneous creation.

\section{Applicable law}

Oil, due to its rarity and scarcity, was initially exploited individually, and later, due to its importance, it was taken over by large oil companies. Internationalization occurs when products are exported by producer countries to the international market, with a clear division of the market. On the one hand, the countries of the Persian Gulf (producers), on the other the countries of Western Europe (consumers). [10] The international character of the oil industry is based, above all, on the diversity of the agents involved (states, international organizations and companies), on the fact that the petroleum reservoirs are often not limited to the geographical limits of the receiving countries, as well as on the diversity of problems it involves. Being the receiving State, or a state company representing the government in question, one of the main protagonists and the other, a company, normally designated by an oil company, originating in another State, acting as a private entity, intending to explore and produce from the natural resources owned by the former, an unequal position between the parties can easily be seen. It was found a need over the years to mitigate this inequality. Foreign companies, as investors, intend, on the one hand, before entering into any agreement, to obtain certain guarantees regarding the full fulfillment of the contract. On the other hand, the receiving States, acting as sovereign entities, may, during the execution of the contract, make major legislative changes, which will inevitably affect the investor's rights and obligations. Consequently, the latter wants to ensure the obligations assumed in the contract at all costs and, therefore, intends to include clauses limiting the performance of States, namely, clauses on stability, hardship and arbitration. [16,17,18 Another concern, no less, is related to the contract's regulatory law. We cannot fail to emphasize the clear insufficiency of national rights to regulate this type of relations and settle all controversies, in addition to investors doubting the impartiality of the application of the national law of the receiving State. If we add to this the strategic importance of the asset involved and the values it entails, we find that only special rules, directed at this sector, will enhance the desired impartiality and technicality. We cannot fail to emphasize the international nature of oil discipline. In addition to the private interests involved, there are also the interests of the receiving States and their populations.

As already mentioned, the specialization of the discipline of oil relations has been taking shape through Lex Petrolea. [13] This normative body, devoted to regulating the multiplicity of relationships that are established in the sector, without being linked to any national legal system, has allowed its acceptance by the States that own natural resources and by the multinationals of the sector, although certain normative rules are relevant the receiving State. It is a sector linked to the public domain and, therefore, headed by the governments of the States, which naturally impose some limitations. The term Lex Petrolea was used in 1958 by the Arbitral Court, which considered the case of ARAMCO versus Saudi Arabia. This Court understood that the national law applicable to the situation should be interpreted and complemented in accordance with General Principles of Law, by the customs and good practices of the oil industry. In 1982, in the case of Kuwait versus AMINOIL, the government in question argued based on a set of arbitration decisions handed down in oil disputes that would have resulted in Lex Petrolea, recognized 
and applicable, in different situations, to the merits of the case, exclusively or subsidiary. [19] In the case of Sapphire International Petroleum versus NIOC, the arbitrators based their decision on Lex Petrolea, appealing to the principle of good faith and cooperation between the parties, thus identifying a set of disciplinary rules for oil contracts, removing the national law of the State of the natural resources' location (host state / recipient of the investment). We should note the case of British Petroleum (BP) versus Libya, where the arbitrators also applied Lex Petrolea in a subsidiary way to fill gaps in Libyan law. [1]

From this jurisprudential list, Lex Petrolea came to establish itself as a customary law for the oil industry, as a branch of Lex Mercatoria. Lex Petrolea's content and effectiveness thus largely depend on the perception of the modern world order, from an economic point of view and its regulation, where the absence of a world government ended up driving transnational regulation, which is nothing more than an autonomous and sectoral form of governance. It is understood that the legitimacy of the system, of its rules, must emerge from its acceptability by the members of the transnational oil society. It was from the sector itself that they emerged, especially through the contractual models that were being consolidated, the codes of conduct and guidelines fostered by associative entities in this industry. In short, the intention is to establish good practices and international standards to be adopted in oil contracts and in arbitrations in the sector. Lex Petrolea's existence and effectiveness thus transnationalizes the oil industry, overcoming the inadequacy of national legislation. This normative source emerges above all from the relations established in international politics, from the action of the NOC's and IOC's, from the political strategies of the States and from the legifying activity. The ways in which it manifests itself can be varied, namely international instruments (lato sensu), standard contracts, usages and customs of the sector, arbitration jurisprudence, among others. Its object lies in the legal protection of a set of situations, which are necessarily linked to the interests, practices and material and immaterial values related to the oil industry. Unlike Lex Petrolea and despite its origin, Lex Mercatoria, as we said, still suffers, for some, from difficult affirmation at Societas Mercatorum, not being able to bring together all the actors of international trade on a global scale, where $\mathrm{i}$ tis possible to consolidate usages and customs, reflecting the concerns of the sectors.

\section{Conclusion}

The oil industry developed initially through the figure of the individual producer. It was found that, as the demand for the product increased, the figure of the individual producer was being replaced by the big oil companies, which started to buy the oil not only for their own use, but also started to explore and commercialize it. This industry was gradually monopolized, with all activities carried out by large economic groups, gaining an international dimension when companies started exporting from producing countries to consuming countries, thus creating an international market. The economies of all industrially and technologically advanced countries have therefore become dependent on oil. The international oil trade created a regulatory specialization, Lex Petrolea, whose creation is justified by the importance of the oil trade and industry in the world, combined with the technical specificities of this activity. The importance of legal autonomy imposed by both Lex Mercatoria and Lex Petrolea, as representatives of the two major driving forces in modern economies - trade and oil - has allowed for a general reflection on the regulation of international trade relations. In fact, the specificities of the sectors, at international level, have demanded adequate legal treatment to the interests of the protagonists, without neglecting the predictability and legal certainty. The inadequacy of national laws has fostered the "deterritorialization" of the discipline of international contracts. Having overcome the customary characteristic of the rules, we are moving towards a non-state legiferation, carried out by entities that have focused on the analysis and study of the great mainstays of international trade. To all this must be added the role of certain organizations, although sectoral, which has contributed to the consolidation of good practices to be adopted by the respective players. De iure condendo, we will say that all these swift, peaceful and highly effective mechanisms for the regulation and resolution of conflicts within the scope of international trade relations and the oil industry itself will hardly be able to regulate relations in an exclusive way, always being imposed, by the State, the defense of public interests, whether economic, social, political or environmental, namely through the international public order, eg lois de police. [14] Finally, it is worth noting the importance of the role assumed by both Lex Mercatoria and Lex Petrolea in their respective sectors and, above all, for their remarkable practical relevance. In short, the globalization of international commercial relations has, in a way, seconded commercial uses, aiming for a more "deterritorialized", cosmopolitan and universal right. Currently, it is referenced the New Lex Mercatoria, covering, in addition to usages and customs, other normative realities, called soft law and emerging from entities that seek the harmonization of rules to discipline international commercial contracts.

\section{References}

[1] Favacho F. Conflict management in international petroleum contracts. Available
http://www.esdc.com.br/RBDC/RBDC-18/RBDC-18-243Artigo_Frederico_Favacho_(A_Gestao_de_Conflitos_em_Contrat os_Internacionais_do_Petroleo).pdf

[2] D'Almeida AL. Oil industry in Brazil and worldwide: training development and ambience current. Sao Paulo: Editora Blucher; 2015.

[3] Intan WS. The analysis factors of experential marketing, product quality, and customer satisfaction of motor bike as a main transportation mode in bandung-indonesia. Int. j. bus. adm. Stud. 2016; 2(1): 6-8.

[4] Cyrne CC. The choice between renewable and non-renewable energy sources: A fallacious dichotomy. Trvista Espacious. 2016; 36(2). Available from https://www.revistaespacios.com/a16v37n26/16372603.html

[5] Kharina Z, Nauly M. The effect of person-organization fit and hardiness on turnover intention among graduate trainee of a private palm oil enterprise in Indonesia. J. adm. bus. stud. 2018; 4(1): 1826

[6] Brandão C. Lex Petrolea. Available from: https://www.epublicacoes.uerj.br/index.php/rbdp/article/view/5732/4171

[7] Gala, FJ. The typicality of atypical contractual forms in international oil trade. The Law Magazine. 2009; 141(4).

[8] Marques, P. (2004). The legal nature of the Production Sharing Agreement (PSA) in the light of the Portuguese legal system. energy studies: oil and natural gas. Portugese: Almedina; 2004.

[9] Baptista LO. International contracts. São Paulo: Lex Editora; 2010.

[10] Mimoso MJ. How oil contracts affect human rights. Europ. $j$. multidiscip. stud. 2018; 3(4):30-39. Available from: http://journals.euser.org/index.php/ejms/article/view/4019

[11] Goldman B. The applicable law: general principles of law - the law mercatoria. In Contemporary problems in international arbitration, London; 1986.

[12]Fortier LY. The New, New Lex Mercatoria, or, Back To The Future. Arbitration Int. 2001; 17(2): 121-128. Available from: https://doi.org/10.1023/A:1011242631762

[13] Otero GC. Reflections on the law applicable to international oil contracts. J. World Energ Law Bus. 2013. Available at: https://core.ac.uk/download/pdf/19722299.pdf

[14] Glitz, FEZ. Lex mercatoria: autonomous legal order? Magazine of the Secretariat of the Permanent Review Court. Mercosur. 2011; 
9(5): 196-223. Available from: http://www.revistastpr.com/index.php/rstpr/article/view/208

[15] Schultz, T. (2011). The concept of law in transnational arbitral legal orders and some of its consequences. J. Int. Dispute Settlement. 2011; 2(1): 59-85. Available from: https://doi.org/10.1093/jnlids/idq019

[16]Cameron, P. D. stabilisation in investment contracts and changes of rules in host countries: tools for oil and gas investors [Internet]. Available from: https://www.international-arbitrationattorney.com/wp-content/uploads/arbitrationlaw4-StabilisationPaper.pdf

[17]Dias ND. Stability in international oil contracts and some of the general principles of related law: from myth to reality. Bar Association Magazine. 2011; 71(3). Available from: https://portal.oa.pt/upl/\%7B4e312b4e-0819-4321-bbbffed917df512c\%7D.pdf

[18] Gjuzi J. The legal status of stabilization clauses under international law: the traditional debate revisited. In: Stabilization clauses in international investment law. Switzerland: Springer; 2018.

[19] Martin T. Lex petrolea in international law. In: King R (eds.) Dispute Resolution in the energy sector: a practitioner's handbook. London: Globe Law and Business; 2012. 